JAMP: Jurnal Adminitrasi dan Manajemen Pendidikan

Volume 2 Nomor 1 Maret 2019, Hal : 17-25

Tersedia Online di http://journal2.um.ac.id/index.php/jamp/

ISSN 2615-8574 (online)

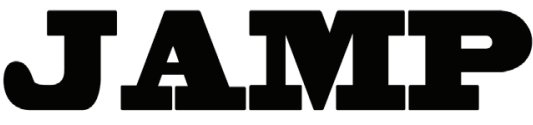

\title{
MANAJEMEN PEMBINAAN AKHLAK DALAM PENGUATAN PENDIDIKAN KARAKTER PESERTA DIDIK
}

\author{
Nuri Shabrina Putri Ardi \\ Ahmad Yusuf Sobri \\ Desi Eri Kusumaningrum
}

e-mail: nurishabrinap@gmail.com

Universitas Negeri Malang, Jl. Semarang No.5 Malang 65145

\begin{abstract}
The purpose of this study is to know the planning of moral development, organizing of moral development, actuating of moral development, controlling of moral development, and several factors that influence the implementation of moral development which is held in SD Negeri Merjosari 4 Malang and SD Negeri Karangbesuki 4 Malang. This research uses qualitative approach and uses multisite study type. The data was collected by using interview, observation, and documentation. The result of this study suggested that SD Negeri Merjosari 4 Malang and SD Negeri Karangbesuki 4 Malang doing the management process in moral development of character education. SD Negeri Merjosari 4 Malang and SD Negeri Karangbesuki 4 Malang do their management process by doing the planning, organizing, actuating, and controlling. There are several factors that influence its implementation, including students, parents, the surrounding environment, and facilities.
\end{abstract}

Keyword: management, moral training, character education

\begin{abstract}
Abstrak: Tujuan penelitian ini adalah untuk mengetahui perencanaan pembinaan akhlak, pengorganisasian pembinaan akhlak, pelaksanaan pembinaan akhlak, evaluasi pembinaan akhlak, dan faktor yang mempengaruhi pelaksanaan pembinaan akhlak yang dilaksanakan di SD Negeri Merjosari 4 Malang dan SD Negeri Karangbesuki 4 Malang. Pendekatan yang digunakan dalam penelitian ini merupakan pendekatan kualitatif, sedangkan jenis penelitian yang digunakan adalah penelitian multisitus. Teknik pengumpulan data dilakukan dengan wawancara, observasi, dan dokumentasi. Hasil penelitian menunjukkan bahwa SD Negeri Merjosari 4 Malang dan SD Negeri Karangbesuki 4 Malang melakukan proses manajemen pada kegiatan pembinaan akhlak dalam pendidikan karakter. SD Negeri Merjosari 4 Malang dan SD Negeri Karangbesuki 4 Malang melaksanakan proses manahemen kegiatan berupa perencanaan, pengorganisasian, pelaksanaan, dan evaluasi. Terdapat beberapa faktor yang mempengaruhi pelaksanaannya, antara lain peserta didik, orang tua, lingkungan sekitar, dan sarana.
\end{abstract}

Kata Kunci: manajemen, pembinaan akhlak, pendidikan karakter

Indonesia kini tengah berada dalam kondisi krisis dan dekadensi moral. Terjadinya kerusakan atau kemerosotan moral di Indonesia disebabkan karena proses pembelajaran yang mengajarkan moral dan budi pekerti hanya sebatas teks dan kurang mempersiapkan generasi penerus untuk menyikapi dan menghadapi kehidupan yang cenderung kontradiktif. Seharusnya, moral dan budi pekerti merupakan sebuah pedoman hidup dan perisai yang dapat menghalangi seseorang dari pengaruh buruk yang ada di sekitar. Selain berpegang pada moral dan budi pekerti, hal lain yang harus dimiliki adalah karakter. Karakter dapat dikatakan sebagai penggabungan dari watak, tabiat, akhlak, ataupun kepribadian seseorang yang terbentuk dari hasil internalisasi berbagai kebijakan yang diyakini dan digunakan sebagai landasan untuk cara pandang, berpikir, bersikap, dan bertindak. 
Karakter adalah suatu hal yang amat mendasar dalam kehidupan berbangsa dan bernegara, lunturnya karakter suatu bangsa dapat menyebabkan hilangnya generasi penerus bangsa yang gemilang. Karakter juga merupakan sebuah 'kemudi' dan kekuatan, yang menyebabkan suatu bangsa kokoh dan tidak terombang-ambing. Karakter tidak datang dengan sendirinya, melainkan harus dibentuk dan dibangun agar generasi penerus bangsa dapat menjadi generasi yang memiliki harkat dan martabat. Pembentukan karakter generasi penerus bangsa tidaklah mudah untuk dilakukan, karena banyak faktor yang mempengaruhinya. Salah satunya yaitu adanya globalisasi, yang telah menyentuh seluruh aspek penting kehidupan.

Globalisasi membawa masyarakat Indonesia melupakan karakter luhur bangsa. Selain melupakan karakter luhur bangsa, masyarakat mengalami demoralisasi terutama pada peserta didik. Kondisi ini menyebabkan bangsa Indonesia mengambil salah satu langkah untuk melindungi kehidupan moral penerus bangsa, untuk sekarang dan/atau selamanya, yaitu dengan pembentukan karakter peserta didik. Berbagai cara dapat dilakukan dalam pembentukan karakter peserta didik, salah satunya melalui pendidikan. Pendidikan karakter merupakan salah satu tanggapan yang diberikan dalam bidang pendidikan bangsa untuk mempersiapkan penerus bangsa yang berkualitas, tidak hanya bagi individu sebagai warga negara, tetapi juga bagi kepentingan masyarakat Indonesia secara keseluruhan. Pelaksanaan pendidikan karakter menjadi suatu hal yang penting untuk dilakukan di jenjang pendidikan manapun, terutama di jenjang pendidikan dasar. Karena pendidikan dasar merupakan pondasi utama dalam tumbuh kembangnya generasi muda penerus bangsa.

Dalam penerapan pendidikan karakter agar dapat berjalan dengan optimal, perlunya peran serta dari berbagai pihak, yaitu keluarga, sekolah, masyarakat sekitar sekolah, dan bahkan masyarakat luas sekalipun. Adanya penerapan pendidikan karakter di sekolah ini memberikan kebebasan pada pihak sekolah untuk memilih atau membuat program yang akan diterapkan di sekolahnya masing-masing yang akan disesuaikan dengan visi dan misi di sekolah, serta keadaan lingkungan sekolah. Pemberian kebebasan memilih atau menerapkan suatu program akan membuat sekolah memiliki beragam kreasi terkait pendidikan karakter, salah satunya adalah penerapan pembinaan akhlak. Pembinaan akhlak merupakan suatu hal yang paling mendominasi dalam pembentukan kepribadian peserta didik. Pemantauan dan pemberian materi seharusnya dilakukan oleh guru secara maksimal. Pembinaan akhlak seharusnya dilakukan sejak pendidikan dasar agar peserta didik memiliki akhlak yang baik saat ini dan seterusnya.

Terkait pembinaan akhlak yang dilaksanakan di sekolah, SD Negeri Merjosari 4 Malang dan SD Negeri Karangbesuki 4 Malang merupakan contoh sekolah dasar yang menerapkan pembinaan akhlak bagi peserta didiknya. Kegiatan pembinaan akhlak di SD Negeri Merjosari 4 Malang dilakukan dengan penerapan Senam, Akhlak, Lagu (SAL). Tidak hanya itu, dalam meningkatkan keimanan dan ketaqwaan, peserta didik SD Negeri Merjosari 4 Malang melaksanakan sholat berjamaah dan mengaji di musholla sekolah. Dalam pelaksanaan pembinaan akhlak, kepala sekolah dan seluruh guru turut berperan dalam membimbing dan membina peserta didik. Berbeda halnya dengan pembinaan akhlak di SD Negeri Karangbesuki 4 Malang. Pembinaan akhlak yang dilaksanakan di SD Negeri Karangbesuki 4 Malang berupa kegiatan belajar mengajar di kelas, ekstrakurikuler, pembiasaan tertib sholat berjamaah, serta kegiatan banjari dan kegiatan Baca Tulis Qur'an (BTQ). Kepala sekolah dan seluruh guru di SD Negeri Karangbesuki 4 Malang juga berperan dalam membimbing dan membina peserta didik. Penerapan kegiatan-kegiatan di dua sekolah tersebut memiliki tujuan, yaitu supaya peserta didik dapat menjadi pribadi yang memiliki intelektual dan memiliki akhlak yang baik.

\section{METODE}

Pendekatan yang digunakan dalam penelitian ini adalah pendekatan kualitatif, sedangkan jenis penelitian yang digunakan adalah studi multisitus Penelitian ini melibatkan beberapa situs dan subjek penelitian sebagai kasus dan diasumsikan memiliki karakteristik yang sama. Kehadiran peneliti dalam penelitian kualitatif sangat penting, karena peran peneliti sebagai kunci utama dalam mencari dan 
menemukan sebuah informasi yang dibutuhkan sesuai dengan fokus penelitian. Peneliti mengumpulkan data di dua sekolah dasar negeri di Kota Malang, yaitu SD Negeri Merjosari 4 Malang dan SD Negeri Karangbesuki 4 Malang. Kedua situs memiliki beberapa kesamaan secara umum, antara lain keduanya merupakan sekolah negeri di Kota Malang. Pelaksanaan kegiatan di dua situs harus dilaporkan pada Dinas Pendidikan Kota Malang. Kedua situs yang diteliti berada di bawah naungan Pemerintah Kota Malang. Alasan peneliti memilih dua sekolah dasar tersebut karena ingin mengetahui apakah dalam menyelenggarakan suatu kegiatan menerapkan fungsi manajemen atau tidak.

Tujuan dari penelitian yang dilakukan yaitu untuk mengetahui informasi lebih dalam mengenai manajemen pembinaan akhlak untuk peserta didik di dua sekolah dasar negeri di Kota Malang, yaitu SD Negeri Merjosari 4 Malang dan SD Negeri Karangbesuki 4 Malang. Sumber data yang dibutuhkan dalam penelitian ini adalah semua data dan/atau informasi yang berkaitan dengan kebutuhan utama sumber data utama dalam penelitian kualitatif. Teknik pengumpulan data yang dilakukan untuk mencapai tujuan penelitian yaitu teknik wawancara, teknik observasi, dan teknik dokumentasi. Teknik pengumpulan data melalui wawancara dilakukan dengan narasumber adalah kepala sekolah, guru sebagai penyelenggara kegiatan dan orang tua dari peserta didik sebagai orang yang mengetahui keseharian peserta didik di lingkungan keluarga.

Analisis data yang digunakan merupakan proses analisis data dari Miles dan Huberman (dalam Ulfatin, 2015:258), yang terdiri dari reduksi data, penyajian data, dan verifikasi. Setelah melakukan proses analisis data, peneliti membuat kesimpulan berupa deskripsi. Peneliti menggunakan beberapa teknik untuk mengecek keabsahan data yang dipaparkan pada penelitian ini, antara lain triangulasi, kecukupan bahan referensi, dan pengecekan anggota.

\section{HASIL}

\section{SD Negeri Merjosari 4 Malang}

SD Negeri Merjosari 4 Malang yang terletak di Jalan Tirtomulyo 38 Kelurahan Merjosari, Kecamatan Lowokwaru, Kota Malang. Pembinaan akhlak yang dilakukan di SD Negeri Merjosari 4 Malang tidak dilaksanakan secara serta merta. Guru dan Kepala SD Negeri Merjosari 4 Malang mengawali adanya pembinaan akhlak dengan melaksanakan perencanaan kegiatan. Perencanaan kegiatan yang dilaksanakan di SD Negeri Merjosari 4 Malang terdiri atas perencanaan intrakurikuler, kokurikuler, dan ekstrakurikuler, termasuk di dalamnya adalah merencanakan kegiatan pembinaan akhlak. Perencanaan kegiatan intrakurikuler, kokurikuler, dan ekstrakurikuler dilaksanakan melalui rapat yang diikuti oleh guru dan kepala sekolah. Namun, dalam rapat perencanaan kegiatan, kepala sekolah menunjuk guru agama untuk mengatur jadwal pelaksanaan pembinaan akhlak. Perencanaan pembinaan akhlak dilaksanakan dengan cara menyusun jadwal pelaksanaan SAL, yang dalam perencanaannya tidak melibatkan semua guru di SD Negeri Merjosari 4 Malang.

Setelah melaksanakan perencanaan kegiatan, Kepala SD Negeri Merjosari 4 Malang melaksanakan pengorganisasian, yaitu memberi tugas kepada guru-guru. Dalam rangka membagi tugas, Kepala SD Negeri Merjosari 4 Malang ini hanya menunjuk dan memberikan tugas kepada dua guru agama Islam sebagai penanggung jawab atas pelaksanaan pembinaan akhlak. Sedangkan pembagian tugas bagi guruguru pengajar yang lain adalah ketika pelaksanaan pembinaan akhlak. Guru di SD Negeri Merjosari 4 Malang diberi tugas oleh kepala sekolah untuk menyampaikan materi pembinaan akhlak kepada peserta didik di halaman SD Negeri Merjosari 4 Malang.

Setelah melakukan pengorganisasian, kegiatan yang dilakukan selanjutnya adalah pelaksanaan. Pelaksanaan kegiatan intrakurikuler di SD Negeri Merjosari 4 Malang yaitu pelaksanaan pembelajaran sehari-hari yang dilakukan oleh peserta didik. Pelaksanaan kegiatan kokurikuler yaitu pelaksanaan kegiatan SAL yang dilaksanakan pada hari Selasa dan hari Kamis wajib diikuti oleh peserta didik mulai dari kelas 1 hingga kelas 6. Kegiatan SAL diawali dengan berdoa bersama dengan seluruh warga sekolah, kemudian seluruh peserta didik dan guru menyanyikan lagu Indonesia Raya, dan dilanjutkan dengan pemberian materi pembinaan akhlak yang disampaikan oleh guru yang telah ditunjuk menjadi 
pembina. Rangkaian kegiatan SAL ditutup dengan pelaksanaan senam yang dilakukan bersama. Kegiatan ekstrakurikuler yang dilaksanakan di SD Negeri Merjosari 4 Malang yaitu kegiatan pramuka, futsal, dan bela diri.

Hal terakhir yang dilaksanakan setelah pelaksanaan adalah evaluasi. Secara keseluruhan, kegiatan yang dilaksanakan oleh peserta didik akan dievaluasi oleh kepala sekolah serta semua guru di SD Negeri Merjosari 4 Malang. Evaluasi yang dilaksanakan dalam kegiatan intrakurikuler, kokurikuler, dan ekstrakurikuler. Evaluasi yang dilaksanakan terkait kegiatan intrakurikuler adalah mengadakan rapat evaluasi di akhir semester. Evaluasi kegiatan kokurikuler dilaksanakan dalam kegiatan mengaji. Evaluasi kegiatan mengaji dilaksanakan melalui buku mengaji yang disebut dengan buku prestasi. Evaluasi kegiatan ekstrakurikuler dilaksanakan dengan membuat laporan masing-masing kegiatan dan dilaporkan pada kepala sekolah.

Dalam pelaksanaan kegiatan-kegiatan yang ada di sekolah, tentu tidak lepas dari faktor-faktor yang mempengaruhi dalam pelaksanaannya. Faktor tersebut dapat berupa faktor pendukung yang dapat membantu terlaksananya kegiatan dengan lancar, maupun faktor penghambat yang dapat memperlambat atau menghambat pelaksanaannya. Faktor yang mempengaruhi terlaksananya pembinaan akhlak adalah peserta didik, lingkungan sekitar, dan sarana penunjang pelaksanaan pembinaan akhlak.

\section{SD Negeri Karangbesuki 4 Malang}

SD Negeri Karangbesuki 4 Malang yang terletak di Jalan Candi III F No. 256 Kecamatan Sukun, Kota Malang. Guru dan Kepala SD Negeri Karangbesuki 4 Malang melaksanakan kegiatan intrakurikuler, kokurikuler, dan ekstrakurikuler, termasuk di dalamnya adalah pelaksanaan pembinaan akhlak bagi peserta didik. Perencanaan kegiatan intrakurikuler dan ekstrakurikuler dilaksanakan dengan rapat yang diikuti oleh guru dan kepala sekolah. Dalam perencanaan kokurikuler, Kepala SD Negeri Karangbesuki 4 Malang menunjuk guru agama untuk menentukan materi yang akan disampaikan pada peserta didik. Hasil dari rapat kepala sekolah dan guru disampaikan pada orang tua peserta didik, serta meminta persetujuan dari orang tua peserta didik.

Kegiatan yang dilaksanakan setelah melakukan perencanaan adalah pengorganisasian. Pengorganisasian yang dilaksanakan bertujuan untuk membagi tugas kepada masing-masing guru. Pengorganisasian dilaksanakan dalam kegiatan intrakurikuler, kokurikuler, dan ekstrakurikuler. Pembagian tugas ditujukan untuk guru di SD Negeri Karangbesuki 4 Malang secara keseluruhan, baik bertanggung jawab terhadap pembelajaran di kelas, dalam kegiatan pembinaan akhlak, maupun kegiatan ekstrakurikuler. Tugas dan kewajiban masing-masing guru adalah membina peserta didik, memberi contoh sifat dan sikap yang baik, serta memberi teguran bagi peserta didik yang bersikap kurang baik. Setiap kegiatan yang dilaksanakan akan ada koordinator yang ditunjuk untuk mempertanggungjawabkan hasil kerjanya dan setiap guru memiliki tugas untuk ikut mengawasi jalannya kegiatan peserta didik di sekolah.

Setelah melaksanakan pengorganisasian, guru dan kepala sekolah beserta seluruh peserta didik merealisasi rencana yang telah disusun. Pelaksanaan kegiatan intrakurikuler di SD Negeri Karangbesuki 4 Malang berupa pelaksanaan pembelajaran yang dilakukan peserta didik setiap hari. Kegiatan kokurikuler dilaksanakan dalam pembinaan akhlak bagi peserta didik, berupa pembiasaan sholat berjamaah, pelaksanaan Baca Tulis Qur'an (BTQ) di kelas masing-masing. Guru memberikan materi pembinaan akhlak dalam pembelajaran agama, memberi contoh yang baik, serta menanamkannya pada peserta didik untuk diterapkan dalam kehidupan sehari-hari. SD Negeri Karangbesuki 4 Malang juga melaksanakan kegiatan ekstrakurikuler, yaitu pramuka, futsal, bela diri, dan banjari.

SD Negeri Karangbesuki 4 Malang melakukan evaluasi setelah melaksanakan seluruh rangkaian kegiatan di sekolah. Evaluasi pelaksanaan pembelajaran dilaksanakan di akhir semester, melalui rapat dan penilaian secara menyeluruh. Evaluasi yang dilaksanakan terkait kegiatan kokurikuler adalah kegiatan BTQ. Evaluasi dilaksanakan melalui buku penilaian yang digunakan untuk memantau perkembangan peserta didik. Buku penilaian kegiatan BTQ disebut dengan buku kemajuan siswa. Sedangkan evaluasi 
yang dilaksanakan terkait kegiatan ekstrakurikuler dengan cara membuat laporan kegiatan dan kemudian disampaikan pada Kepala SD Negeri Karangbesuki 4 Malang.

Dalam pelaksanaan pembinaan di SD Negeri Karangbesuki 4 Malang juga terdapat faktor yang mempengaruhi, dua faktor yang mempengaruhi pelaksanaan pembinaan akhlak di SD Negeri Karangbesuki 4 Malang yaitu faktor pendukung dan faktor penghambat. Faktor-faktor yang mempengaruhi pelaksanaan pembinaan akhlak di SD Negeri Karangbesuki 4 Malang antara lain peserta didik, orang tua, dan lingkungan sekitar.

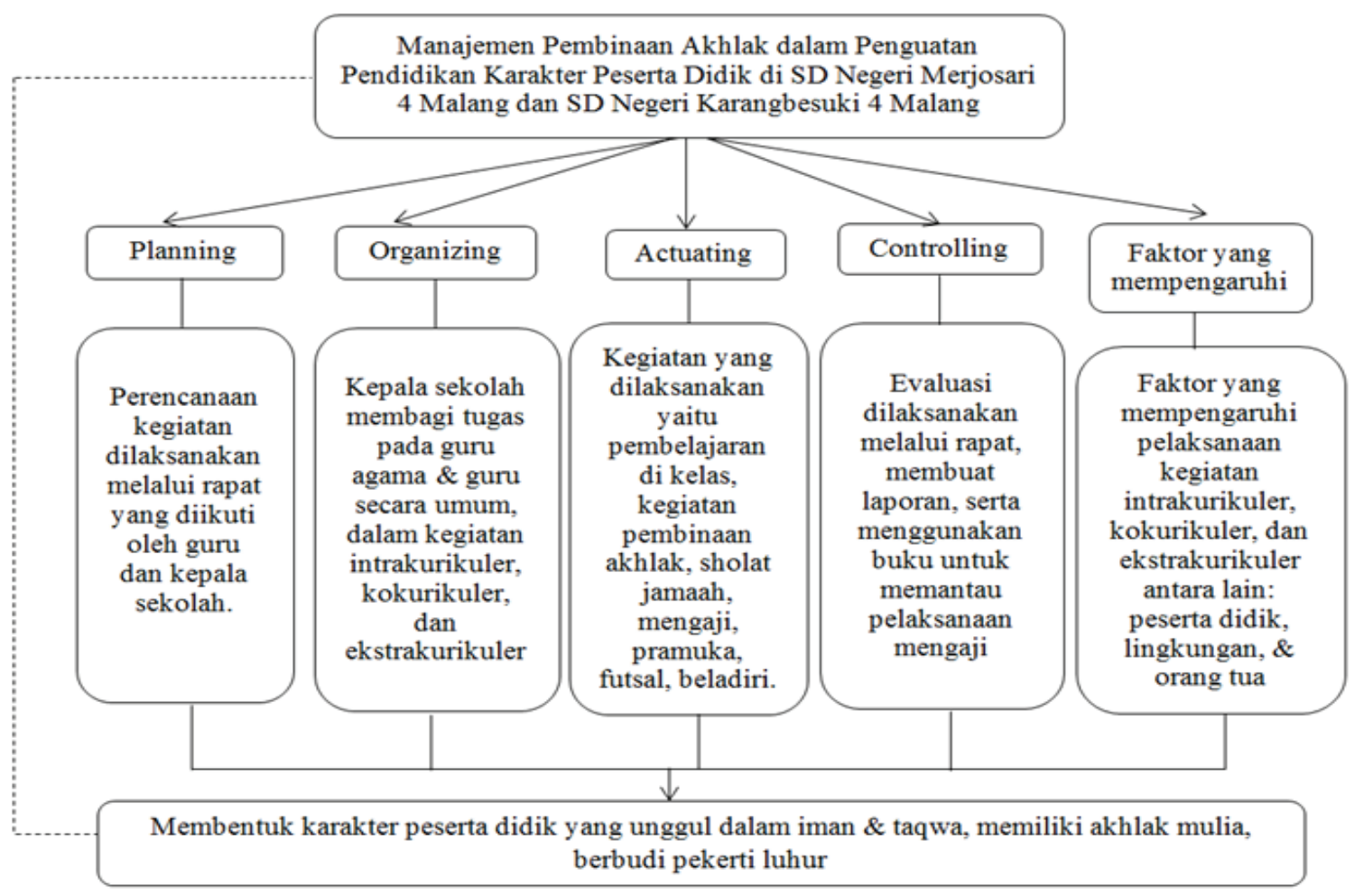

\section{PEMBAHASAN}

Penyelenggaraan suatu kegiatan tidak lepas dari adanya manajemen. Manajemen yang dimaksud dalam hal ini adalah yang diungkapkan oleh Sudjana (dalam Wibowo, 2013:33) yaitu semua kegiatan yang diselenggarakan oleh seseorang atau lebih dalam suatu kelompok atau organisasi/lembaga, untuk mencapai tujuan organisasi/lembaga yang telah ditetapkan. Sejalan dengan hal tersebut, Sutopo (dalam Mulyono, 2008:16), mengemukakan bahwa manajemen adalah proses pencapaian tujuan melalui kegiatan-kegiatan dan kerjasama orang-orang lain. Begitu pula kegiatan-kegiatan yang diselenggarakan di dua sekolah dasar di Kota Malang, yaitu SD Negeri Merjosari 4 Malang dan SD Negeri Karangbesuki 4 Malang. Dalam menyelenggarakan kegiatan pembinaan akhlak melibatkan guru, kepala sekolah, dan juga peserta didik guna mencapai tujuan yang telah ditetapkan sebelumnya. Terlaksananya seluruh kegiatan di sekolah juga atas dukungan dan adanya kerjasama dengan berbagai pihak untuk mencapai tujuan secara efektif dan efisien.

\section{Perencanaan Program Pembinaan Akhlak}

Perencanaan yang dilaksanakan di SD Negeri Merjosari 4 Malang terkait dengan kegiatan intrakurikuler, kokurikuler, dan ekstrakurikuler, termasuk di dalamnya adalah perencanaan pembinaan akhlak. Perencanaan kegiatan intrakurikuler dan ekstrakurikuler dilaksanakan melalui rapat. Perencanaan kegiatan kokurikuler juga dilaksanakan melalui rapat. Namun dalam rapat yang dilaksanakan, kepala sekolah menunjuk guru agama untuk merencanakan kegiatan pembinaan akhlak. Perencanaan kegiatan pembinaan akhlak dilaksanakan dengan membuat jadwal kegiatan. Jadwal yang disusun berisi tanggal, nama pembina, serta tema materi yang akan disampaikan ketika pelaksanaan. Diterapkannya program 
SAL dua kali dalam satu minggu diharapkan peserta didik yang mengikuti kegiatan tersebut mendapat materi meskipun tidak semuanya. Hal yang dijadikan sebuah dasar dalam merencanakan pendidikan karakter yaitu adanya perbedaan pada diri peserta didik terutama daya tangkap informasi. Tidak hanya itu, sifat dan karakter peserta didik di SD Negeri Merjosari 4 Malang juga berbeda-beda.

Perbedaan sifat dan karakter, serta daya tangkap informasi peserta didik inilah yang mendasari adanya pelaksanaan program SAL di SD Negeri Merjosari 4 Malang. Hal ini serupa dengan yang dijelaskan oleh Sobri (2015b), bahwa pendidikan yang berorientasi pada pengembangan karakter didasarkan atas cara pandang bahwa para siswa adalah bibit-bibit yang mempunyai potensi keunggulan yang beragam. Mereka bukan bibit yang seragam atau sejenis, dan justru terdiri dari perbedaan individu yang satu dengan lainnya darimana potensi kreatifnya bersumber.

Situs kedua yang diteliti yaitu SD Negeri Karangbesuki 4 Malang, juga melaksanakan fungsi manajemen ini. Kegiatan-kegiatan intrakurikuler, kokurikuler, dan ekstrakurikuler yang dilaksanakan di SD Negeri Karangbesuki 4 Malang direncanakan melalui rapat yang diikuti oleh guru dan Kepala SD Negeri Karangbesuki 4 Malang. Salah satu kegiatan yang direncanakan adalah pembinaan akhlak. Hasil dari rapat yang diselenggarakan akan disampaikan kepada orang tua peserta didik, guna meminta persetujuan untuk melaksanakan kegiatan pembinaan akhlak tersebut. Pemilihan bentuk kegiatan khususnya kegiatan-kegiatan pembinaan akhlak ataupun pendidikan karakter yang akan dilaksanakan oleh peserta didik didasari oleh visi dan misi yang diemban oleh sekolah.

Perencanaan kegiatan pembinaan akhlak di SD Negeri Karangbesuki 4 Malang pun melibatkan orang tua peserta didik, hal ini ditunjukkan dengan adanya sosialisasi pada orang tua peserta didik terkait pendidikan karakter di sekolah. Hal ini sesuai dengan hasil penelitian yang dilaksanakan oleh Maunah (2015), yaitu bentuk penanaman pendidikan karakter di MTsN Jabung Blitar dan di SMPN 1 Talun Blitar dilaksanakan terintegrasi ke dalam visi dan misi sekolah yang diimplementasikan melalui pembelajaran di semua bidang mata pelajaran dan melalui kerja sama dengan keluarga orang tua siswa dan masyarakat.

\section{Pengorganisasian Program Pembinaan Akhlak}

Fungsi manajemen selanjutnya adalah fungsi pengorganisasian. Kepala SD Negeri Merjosari 4 Malang dan Kepala SD Negeri Karangbesuki 4 Malang memberi tugas atau tanggung jawab kepada beberapa guru yang telah ditunjuk untuk menjadi koordinator kegiatan. Guru lain yang tidak menjadi koordinator kegiatan juga diberikan tugas. Guru di SD Negeri Merjosari 4 Malang diberi tugas untuk memberikan materi pembinaan akhlak pada peserta didik sesuai dengan jadwal yang telah ada.

Pembagian tugas juga dilaksanakan di SD Negeri Karangbesuki 4 Malang, dengan melibatkan seluruh guru, sehingga seluruh guru mendapatkan tugas dan memiliki tanggung jawab sendiri-sendiri. Pengorganisasian di SD Negeri Karangbesuki 4 Malang dilakukan dengan membagi tugas pada beberapa guru, sedangkan tugas bagi guru secara keseluruhan adalah membina peserta didik, memberi contoh sifat dan sikap yang baik, memberikan teguran bagi peserta didik yang bersikap kurang baik, serta turut mengawasi jalannya kegiatan-kegiatan di sekolah.

Pengorganisasian di SD Negeri Merjosari 4 Malang dan SD Negeri Karangbesuki 4 Malang ini turut melibatkan seluruh warga sekolah. Terdapat beberapa guru yang mendapatkan tugas lebih, yaitu sebagai penanggung jawab sebuah kegiatan. Adanya pembagian tugas pada guru di kedua sekolah menciptakan kerjasama di antara para guru. Adanya kerjasama dan komunikasi yang baik antar guru di sekolah menyebabkan kegiatan yang direncanakan akan berjalan dengan baik. Hal ini serupa dengan penelitian yang dilakukan oleh Sobri (2015a) bahwa, "kegiatan akan berjalan dengan baik apabila didukung oleh seluruh komunitas yang ada di dalam organisasi itu, seperti yang ditunjukkan oleh semua warga SDI Surya Buana. Semua warga saling membantu dalam pelaksanaan kegiatan yang telah dijalankan.” 


\section{Pelaksanaan Program Pembinaan Akhlak}

Fungsi manajemen yang ketiga adalah pelaksanaan. Setiap sekolah melaksanakan pendidikan karater bagi peserta didiknya, seperti halnya SD Negeri Merjosari 4 Malang dan SD Negeri Karangbesuki 4 Malang. Menurut Kesuma (2013), terdapat 3 desain pendidikan karakter, yaitu pendidikan karakter berbasis kelas, pendidikan karakter berbasis kultur sekolah, dan pendidikan karakter berbasis komunitas. Pada situs yang pertama, yaitu SD Negeri Merjosari 4 Malang cenderung menerapkan desain pendidikan karakter yang kedua, yakni desain pendidikan karakter berbasis kultur sekolah. Dikatakan demikian karena di SD Negeri Merjosari 4 Malang memiliki budaya yang ditanamkan pada peserta didiknya. Pelaksanaan SAL, mengaji, serta pembiasaan sholat berjamaah ini merupakan contoh budaya yang diterapkan di SD Negeri Merjosari 4 Malang.

Berbeda halnya dengan desain pendidikan karakter di situs yang kedua, desain pendidikan karakter pada situs kedua yaitu SD Karangbesuki 4 Malang cenderung menerapkan desain yang pertama, yakni desain pendidikan karakter berbasis kelas. Disebut demikian karena pada SD Negeri Karangbesuki 4 Malang menyelipkan materi-materi akhlak dalam kegiatan sehari-hari, termasuk dalam kegiatan pembelajaran di kelas.

Pembinaan akhlak yang dilaksanakan di SD Negeri Merjosari 4 Malang berupa pemberian materi mengenai akhlak, adab, etika, yang seharusnya dilakukan oleh mereka selaku peserta didik di sekolah, selaku anak di rumah, dan juga bagaimana menjadi bagian dari masyarakat yang memiliki moral dan etika dalam berucap maupun berperilaku. Sedangkan SD Negeri Karangbesuki 4 Malang melaksanakan pembinaan akhlak berupa pembiasaan sholat berjamaah, Baca Tulis Qur'an (BTQ), pelaksanaan ekstrakurikuler, dan pelaksanaan pembelajaran yang juga menyelipkan materi-materi mengenai pembinaan akhlak bagi peserta didik. Memberikan materi pembinaan akhlak dalam pembelajaran agama, memberi contoh yang baik, serta menanamkannya pada peserta didik untuk diterapkan dalam kehidupan sehari-hari. Hal ini sejalan dengan penelitian Sobri (2015a), yaitu penanaman nilai-nilai pendidikan karakter selain diterapkan dalam kehidupan sehari-hari di sekolah, juga diintegrasikan terutama ke dalam proses pembelajaran di dalam kelas. Hal ini dikarenakan pendidikan karakter tidak dapat berdiri sendiri tetapi perlu disisipkan pada setiap pembelajaran yang dilakukan agar berjalan secara efektif.

Pembinaan akhlak dilakukan untuk mengajarkan pada peserta didik mengenai apa yang seharusnya dilakukan dan apa yang seharusnya tidak dilakukan oleh peserta didik. Tidak hanya itu, menerapkan pembiasaan yang baik bagi peserta didik sejak dini juga perlu dilakukan, agar kebiasaan baik tersebut mendarah daging seiring tumbuh kembang peserta didik. Hal ini senada dengan yang dijelaskan oleh Suryaman \& Karyono (2018), pendidikan karakter tidak hanya sekedar mengajarkan mana yang benar dan mana yang salah kepada siswa, tetapi untuk menanamkan kebiasaan (habituation) tentang yang baik sehingga siswa dapat memahami, mampu merasakan, dan mau melakukan yang baik. Jadi, pendidikan karakter membawa misi yang sama dengan pendidikan akhlak atau pendidikan moral di sekolah.

Kedua situs yang diteliti menerapkan pembinaan akhlak bagi peserta didiknya melalui cara yang sedikit berbeda. Sekolah memiliki wewenang untuk menyusun dan melaksanakan program sekolah yang disesuaikan dengan kondisi sekitar sekolah, kondisi peserta didik, dan juga sumber daya yang dimiliki. Hal ini dijelaskan oleh Judiani (2010) yang mengemukakan bahwa sekolah bebas untuk memilih dan menerapkan nilai-nilai yang hendak dibangun dalam diri siswa.

\section{Evaluasi Program Pembinaan Akhlak}

Fungsi manajemen yang terakhir adalah evaluasi. Wibowo (2015:63) mengemukakan bahwa dalam fungsi pengawasan terdapat kegiatan menilai dan monitoring, kegiatan pengawasan ditujukan pada seluruh kegiatan organisasi, dan pengawasan dilakukan dengan tujuan pokok untuk membuat segenap kegiatan administrasi dan manajemen berjalan sesuai dengan rencana, dinamis, dan berhasil secara efektif dan efisien. 
Secara keseluruhan, kegiatan-kegiatan yang dilaksanakan oleh peserta didik akan dievaluasi oleh kepala sekolah dan guru di SD Negeri Merjosari 4 Malang. Kejadian yang ada pada minggu sebelumnya akan dibahas ketika pelaksanaan upacara bendera pada hari Senin, kejadian pada hari Senin akan dibahas pada hari Selasa ketika melaksanakan kegiatan SAL, kejadian hari Selasa atau Rabu dibahas pada hari Kamis saat pelaksanaan SAL, dan terus seperti itu. Evaluasi ini dilaksanakan secara verbal, oleh kepala sekolah atau guru kepada peserta didik, dengan tujuan agar tidak terjadi kesalahan yang sama ke depannya. Sobri (2015a) menjelaskan bahwa "semua aktivitas yang dilakukan harus dievaluasi agar dapat dilihat ketercapaian kegiatan yang telah dilaksanakan."

Fungsi pengendalian terdiri atas pemantauan (monitoring) dan evaluasi, atau dapat disingkat sebagai ME. Menurut Wibowo (2015:61), pengawasan adalah proses pemantauan, penilaian, dan pelaporan rencana atas pencapaian tujuan yang telah ditetapkan untuk tindakan korektif guna penyempurnaan lebih lanjut. Berdasarkan wawancara yang telah dilaksanakan, bentuk evaluasi yang dilaksanakan yaitu penilaian secara menyeluruh terhadap kegiatan yang telah dilaksanakan, membahas progres kegiatan yang dilaksanakan, melakukan evaluasi kekurangan atau kesalahan yang ada, kemudian melakukan perbaikan dari kekurangan maupun kesalahan yang ada, agar pada pelaksanaan berikutnya dapat berjalan dengan lebih baik. Hal ini juga senada dengan hasil penelitian Sobri (2015a), yakni keberhasilan atau kegagalan kegiatan dapat diketahui hasilnya apabila ada kegiatan evaluasi. Evaluasi kegiatan dilakukan untuk menilai dua hal, yaitu proses kegiatan dan hasil kegiatan. Oleh karena itu, pentingnya kegiatan evaluasi juga menjadi perhatian kepala sekolah.

Evaluasi di SD Negeri Karangbesuki 4 Malang dengan cara dirapatkan oleh seluruh guru beserta kepala sekolah. Guru di SD Negeri Karangbesuki 4 Malang membuat laporan terkait pelaksanaan kegiatan pembelajaran maupun kegiatan pembinaan akhlak di sekolah. Seperti yang dikemukakan oleh Sobri (2015a), yaitu "biasanya setiap kegiatan yang telah dilaksanakan akan dilaporkan kepada kepala sekolah baik secara lisan maupun tertulis yang disampaikan di dalam forum rapat guru."

\section{Faktor Pendukung dan Faktor Penghambat Pembinaan Akhlak}

Penyelenggaraan suatu kegiatan tidak luput dari adanya faktor pendukung dan faktor penghambat. Begitu pula dengan penyelenggaraan program pembinaan akhlak di dua situs yang diteliti. Faktor pendukung merupakan hal yang dapat mendorong atau menunjang pelaksanaan suatu kegiatan, faktor tersebut dapat berasal dari internal maupun eksternal. Faktor penghambat merupakan hal yang dapat membuat suatu kegiatan atau pekerjaan menjadi tidak lancar atau lambat, seperti halnya faktor pendukung, faktor penghambat juga dapat berasal dari internal maupun eksternal.

Faktor yang mempengaruhi pelaksanaan pembinaan akhlak di SD Negeri Merjosari 4 Malang adalah peserta didik, lingkungan sekitar, dan sarana penunjang. Sedangkan faktor yang mempengaruhi pelaksanaan pembinaan akhlak di SD Negeri Karangbesuki 4 Malang antara lain peserta didik, lingkungan sekitar, dan orang tua peserta didik. Hal ini serupa dengan hasil penelitian yang dilakukan oleh Manan (2017), faktor pendukung dan penghambat antara lain: (1) orang tua, (2) pendidik atau guru, dan (3) peserta didik.

Faktor pendukung dan penghambat yang ada di SD Negeri Merjosari 4 Malang dan SD Negeri Karangbesuki 4 Malang memiliki beberapa persamaan dan perbedaan. Persamaan faktor yang terdapat di kedua situs tersebut antara lain: faktor peserta didik dan faktor lingkungan sekitar (pergaulan dan keluarga), sedangkan perbedaannya terdapat pada faktor sarana yang kurang memadai. Kedua faktor yang sama tersebut juga dijelaskan dalam penelitian yang dilaksanakan oleh Manan (2017), yaitu faktor keluarga/orang tua dan faktor peserta didik. Manan (2017) juga menyebutkan bahwa dalam faktor pendukung dan penghambat, guru atau pendidik turut mengambil peran, sedangkan dalam wawancara yang dilakukan dengan warga SD Negeri Merjosari 4 Malang dan SD Negeri Karangbesuki 4 Malang tidak terdapat faktor guru atau pendidik di dalamnya. Adanya perbedaan dalam hal faktor pendukung dan faktor penghambat disebabkan karena dalam pelaksanaan pendidikan karakter tidak selalu sama antara sekolah satu dengan sekolah yang lain, sekolah diberi kewenangan untuk memilih penerapan pendidikan karakter yang seperti apa. 


\section{KESIMPULAN}

Kedua situs melaksanakan fungsi perencanaan, yaitu kegiatan persiapan melalui perumusan untuk menetapkan suatu keputusan dalam menyelenggarakan suatu kegiatan, perencanaan dilakukan dengan cara rapat yang membahas kegiatan intrakurikuler, kokurikuler, dan ekstrakurikuler. Pengorganisasian di SD Negeri Merjosari 4 Malang dan SD Negeri Karangbesuki 4 Malang ini turut melibatkan seluruh guru dalam melaksanakan pembagian tugas di sekolah, serta menunjuk beberapa guru untuk bertanggung jawab terhadap pelaksanaan kegiatan intrakurikuler, kokurikuler, dan ekstrakurikuler. Kepala SD Negeri Merjosari 4 Malang dan Kepala SD Negeri Karangbesuki 4 Malang membagi tugas kepada guru di sekolah masing-masing agar melaksanakan tugas yang diberikan dengan sebaik-baiknya.

Semua sekolah melaksanakan pendidikan karakter dengan cara yang beragam, seperti di SD Negeri Merjosari 4 Malang dan SD Negeri Karangbesuki 4 Malang. Sekolah memiliki wewenang untuk menyusun dan melaksanakan program-program sekolah yang disesuaikan dengan kondisi lingkungan sekitar sekolah, kondisi peserta didik, dan juga sumber daya yang dimiliki. Dalam hal evaluasi atau pengendalian, kedua sekolah melaksanakan pengendalian kegiatan dengan cara yang serupa. Pengendalian kegiatan intrakurikuler melalui rapat di akhir semester, pengendalian kokurikuler dalam hal mengaji dilaksanakan melalui buku pengendalian. Pengendalian kegiatan ekstrakurikuler dilaksanakan dengan membuat laporan kegiatan dan kemudian disampaikan kepada kepala sekolah.

Faktor pendukung dan faktor penghambat yang ada dalam pelaksanaan sebuah kegiatan berbedabeda antara sekolah yang satu dengan sekolah yang lain. Adanya perbedaan dalam hal faktor pendukung dan faktor penghambat disebabkan karena dalam pelaksanaan pendidikan karakter tidak selalu sama antara sekolah satu dengan sekolah yang lain, karena sekolah diberi kewenangan untuk memilih penerapan pendidikan karakter yang seperti apa. Pemilihan pendidikan karakter yang diterapkan disesuaikan dengan visi misi serta kondisi sekolah tersebut.

\section{DAFTAR RUJUKAN}

Judiani, A. 2010. Implementasi Pendidikan Karakter di Sekolah Dasar Melalui Penguatan Pelaksanaan Kurikulum. Jurnal Pendidikan dan Kebudayaan, Vol. 16, Edisi Khusus III, Oktober 2010. (Online),(http:/jurnaldikbud. kemdikbud.go.id/index.php/jpnk/article/view/519/358), diakses 17 September 2018.

Kesuma, D., Triatna, C., \& Permana, J. 2013. Pendidikan Karakter: Kajian Teori dan Praktik di Sekolah. Bandung: PT Remaja Rosdakarya Offset.

Manan, S. 2017. Pembinaan Akhlak Mulia Melalui Keteladanan dan Pembiasaan. Jurnal Pendidikan Agana Islam - Ta'lim, Vol. 15 No. 1 - 2017. (Online), (http://jurnal.upi.edu/file/05_PEMBINAAN_AKHLAK_MULIA_Manan1.pdf), diakses 17 September 2018.

Maunah, B. 2015. Implementasi Pendidikan Karakter dalam Pembentukan Kepribadian Holistik Siswa. (Online), (https://journal.uny.ac.id/index.php/jpka/article/view/8615) diakses 8 November 2018.

Mulyono. 2008. Manajemen Administrasi \& Organisasi Pendidikan. Yogyakarta: Ar-Ruzz.

Sobri, A. 2015a. Manajemen Pendidikan Karakter Berbasis Religi di Sekolah Dasar. (Online), (http://journal2. um.ac.id/index.php/sd/article/view/1347) diakses 27 November 2018.

Sobri, A. 2015b. Menumbuhkan Nilai Karakter Siswa di Sekolah. (Online), (http://ap.fip.um.ac.id/wp-content/ uploads/2015/10/1-ahmad-yusuf-sobri.pdf) diakses 27 November 2018.

Suryaman \& Karyono. 2018. Revitalisasi Pendidikan Karakter Sejak Usia Dini di Kelas Rendah Sekolah Dasar. (Online), (http://journal2.um.ac.id/index.php/sd/article/view/3239) diakses 30 November 2018.

Ulfatin, N. 2015. Metode Penelitian Kualitatif di Bidang Pendidikan: Teori dan Aplikasinya. Malang: Media Nusa Cerative.

Wibowo, A. 2013. Manajemen Pendidikan Karakter di Sekolah: Konsep dan Praktik Implementasi. Yogyakarta: Pustaka Pelajar. 